\title{
CURRENT SITUATION OF MEDICINE III AND CHALLENGES
}

\author{
Situação atual da Medicina III e desafios
}

Lydia Masako FerReIRA ${ }^{1,2}$

A B STRACT

\begin{abstract}
Objective: Describe the current situation of the area Medicine III of CAPES and detect challenges for the next four years of evaluation. Methods: The area's documents and reports of meetings were read from 2004 to 2013 Medicine III Capes as well as reports and evaluation form of each Postgraduate Program (PPG) of the area and the sub-page of the area from the Capes website. The data relating to the evaluation process, the assessment form and faculty, student and scientific production data of all of Post-Graduate Programs of Medicine III were computed and analyzed. From these data were detected the challenges of the area for the next four years (2013-2016). Results: Among the 3,806 PPG, Medicine III had 41 PPG during last triennial evaluation and progressed from 18\% to $43 \%$ of PPG very good or more concept (triennium 2001-2003 and 2010-2012). Most PPG were located in the South-East region (32), three in the South and two in the North-East. There was no PPG in North or Central-West regions. In 2013 and 2014 there were four approved Professional Master Degree Programs and one Master (M) and Doctorate (PhD). The average of permanent professors was 558 teachers with about three students/professor. The number of PhD graduates has increased as well as the reason PhD/MD. The proportion of in high impact periodicals (A1, A2, B1 and B2) jumped from 30\% to 50\% demonstrating positive community response to the policy area. The challenges identified were: decrease regional asymmetry, increase the number of masters and doctors of excellence, reassessment of Brazilian journals, stimulate and set internationalization indicators, including post-doctors and definition of its indicators, the PPG nucleation analysis, PPG 3×3, include primary and secondary education, professional master and indicators of technological scientific production and solidarity. Conclusion: Medicine III has been scientifically consolidated and their scientific researchers demonstrated maturity reaching a high level and matched to areas of greatest tradition and history. For the maintenance and advancement of the area some challenges and goals were established to be developed in the period from 2013 to 2016.
\end{abstract}

Key Words: Education, Medical Graduate. Educational Measurement. Education Higher. Health Research Evaluation. Evaluation of Research Programs and Tools

\section{INTRODUCTION}

T he Coordination of Higher Education Personnel Training (CAPES), foundation of the Ministry of Education (MEC) of Brazil, was established in 1951 to play a key role in the expansion and consolidation of post-graduate studies (master's, doctoral and post-doctoral) and more recently (2007) in the formation of Basic Education teachers in all states of the country ${ }^{1}$.

CAPES' activities can be grouped into five major lines of action, each developed by a structured set of programs: evaluation of the strict sense post-graduatioon; access and dissemination of scientific production; investments in high-level training resources at home and abroad; promotion of international scientific cooperation; induction and development of initial and continuing training of teachers for basic education in the presential and at distance ${ }^{1}$

Among Capes actions, evaluation of research in Brazil is one of the nation's best processes that have worked with efficiency and proven effectiveness. So much so, that the process has been taken to the Evaluation of Medical Residence and of Elementary School.

The evaluation has the role of analyzing the panorama of post-graduate programs (PPG) in Brazil, and thus attest to the quality of the courses and monitor the qualification. From the evaluation is obtained elements and indicators to induce and encourage government actions in support of the Brazilian post-graduation. As a result it can make plans and adjustments to advance the sciences and technologies and develop the country, for example pursue specific programs to reduce disparities between regions of Brazil or within and between areas of knowledge.

So, the aim of this study is to describe the current situation of the area of Medicine III of CAPES and experience the challenges for the next four years of evaluation.

\section{METHOD}

To access all the data relating to PPG of Medicine III of CAPES, documents and meeting area and reports from 2004 through 2013 were read, as well as the reports and evaluation sheets of each PPG area beyond the access subpage area at the Capes site. $2,3,4,5$

The data relating to evaluation process, the evaluation form and the data of the requisites and sub-requisites of the teachers (CD), the Student Body $(C d) / T h e s e s(T)$, the scientific production (PC) and social inclusion (IS ) of all PPG of Medicine III, were computed and analyzed. From these data were detected the challenges of the area for the next four years (2013-2016).

\section{RESULTS}

In Brazil there are 3,806 post-graduate programs with 1,282 academic master degrees (MA), 62 academic doctorates (CA) and 579 professional master's degrees (MP) described in the Capes site updated on 17/11/2014. In terms of post-graduate courses (CPG) there are 5,689 courses, 3,165 MA, 1945 $\mathrm{DA}$ and $579 \mathrm{MP}^{2}$

These PPG are divided into three colleges: College of Life Science, College of Exact Sciences, Technology and Multidisciplinary and Humanities College. The Agricultural, Biological and Health Sciences are included in Life Sciences College. Medicine III, as well as the Medicines I and II, Physical Education, Nursing, Pharmacy, Nutrition, Dentistry and Public Health Sciences belong to Health Sciences ${ }^{3}$.

Medicine III includes 41 PPG, being one as MA only, four as DA only, 32 as $M$ and DA, and four as MP. If we analyze the CPG, there are 73 CPG being $33 \mathrm{MA}, 36 \mathrm{DS}$ and four MP3,4,5.

The evaluation process of these courses follows four Capes normative: impartial peer-review in each area, discussed criteria and updated after every evaluation period, transparency with full disclosure in Capes portal and approval in the Technical Scientific Council of Higher Education (CTC-ES) . It is based on the triad: the evaluation form, evaluation reports and documents of the areas that can be found in the area sub-page on Capes site ${ }^{4,5}$.

The Capes board calls to double the indication of staffing consultants (one consultant for every three PPG) for the selection process to be held on the Superior Council (CS). Medicine III has indicated names of researchers from various surgical specialties (not favoring any), following the regionality, institutional homogeneity, academic positions, impartiality, commitment, 
responsibility and availability.

After indication of consultants by CS Capes, Medicine III called for eight stages for evaluating the PPG: prior training of consultants; online distribution of PPG for each consultant (for classification grade of PPG and respecting non-institutional inbreeding and the federal state); individual analysis of each PPG for at least three consultants; meeting with all consultants in São Paulo for the presentation of the evaluation form (FA) (previously discussed by the sub-committee on Improvement Evaluation Form) and the presentation of each PPG, lasting three days; meeting with all consultants in São Paulo for the presentation of each PPG, lasting three days; meeting with all consultants in São Paulo for the presentation of PPG had their lowered notes, notes 6 and 7 and notes $3 \times 3$ (three times of three years followed note 3), lasting two days; formal evaluation meeting in Brasilia with all consultants for reviewing the FA of all PPG, for processing in the Capes system and to make the final report of the evaluation process; approval in CTC-ES ${ }^{4,5}$

FA is supported by five major areas: Program Proposal (weightless), Faculty (weight $=20 \%)$, Student/Theses $(35 \%)$, Intellectual Production (35\%) and Social Inclusion (10\%) ${ }^{4}$.

The evolution of Medicine III was certainly a very important stimulus to the surgical area. In the period 2001-2003 there were only $18 \%$ (9) PPG note with $>5$ and no PPG notes 6 and 7 (international levels). Over the next two three-year periods (2004-2006 and 2007-2009) the number of PPG with very good concept or above was $35 \%$ and $38 \%$. And for the first time the area had a PPG note 7 and note 6 . The scientific consolidation and maturity of the researchers of Medicine III occurred in the past three years from 2010 to 2012 when 43\% (11) PPG concept had equal or higher than very good ( >note 5) and four PPG (two note 6 and two note 7 ) were conceptualized with international competitiveness 4 . Most PPG in Medicine III and the international level PPG (notes 6 and 7) are located in the Southeast (Figure 1) ). $^{4 .}$

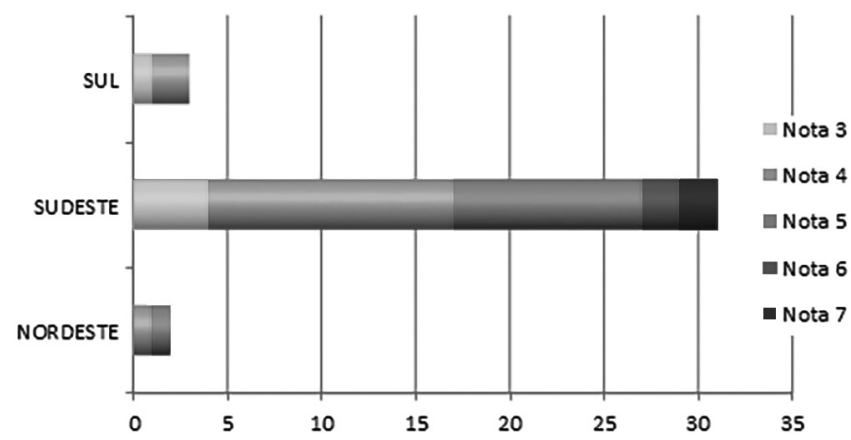

FIGURE 1. Distribution of PPG by geographic region and grade classification in the triennial evaluation by Capes 2010-2012

Table 1 shows the number of PPG by state and classification of notes until 01/2015, including new courses approved in 11/2014. Two CPG were not included in the table because they were in diligence. After this step they will be re-assessed in CTC Capes.

\section{Table 1 - Number and classification of grades of PPG/State}

\begin{tabular}{|l|c|c|c|c|c|c|}
\hline State/Note & " $n$ " PPG & Note 7 & Note 6 & Note 5 & Note 4 & Note 3 \\
\hline SP $(65 \%)$ & $28(2 \mathrm{MF})$ & 2 & 2 & 9 & 11 & $4(2 \mathrm{MP})$ \\
\hline RJ (7\%) & $3(1 \mathrm{MF})$ & - & - & 1 & 1 & 1 (MF) \\
\hline MG (7\%) & $3(1 \mathrm{MF})$ & - & - & - & 2 & $1(\mathrm{MA})$ \\
\hline PR $(4,6 \%)$ & 2 & - & - & - & 1 & 1 \\
\hline RS $(4,6 \%)$ & 2 & - & - & - & 2 & - \\
\hline CE $(4,6)$ & $2(1 \mathrm{MP})$ & - & - & 1 & - & $1(\mathrm{MP})$ \\
\hline PE $(2,3 \%)$ & 1 & - & - & - & 1 & - \\
\hline PA $(2,3 \%)$ & $1(\mathrm{MP})$ & - & - & - & - & $1(\mathrm{MP})$ \\
\hline PI $(2,3 \%)$ & $1(\mathrm{MP})$ & - & - & - & - & $1(\mathrm{MP})$ \\
\hline Total & $43(7 \mathrm{MP})$ & 2 & 2 & 11 & 18 & $10(6 \mathrm{MP})$ \\
\hline
\end{tabular}

The $C D$ had adequate proportion between the different modalities, the vast majority of permanent teachers (DP), few collaborators and some visitors. Averaged 558 DP (521 in 2010, 573 in 2011 and 580 in 2012), an average of 86 collaborators teachers (DC) (83, 86 and 91 in 2010, 2011 and 2012) and average of eight visitors (DV) (11, 7:07 in 2010, 2011 and 2012) 4.5.

Medicine III has emphasized the importance of DP categorize as CNPq researcher and the data show that there was a positive response of the academic community to the policy area. The evolution of the percentage of CNPq researchers was from $2 \%$ to $5 \%$ and $7 \%$ in the last three study periods.

At the beginning of the creation of PPG in the surgical area the student body was composed $100 \%$ of surgeons. Currently this number became $30 \%$ to $50 \%$ depending on the PPG, due to the interdisciplinary and on behalf of seduction of working life.

The number of theses and dissertations in the three-year 2010-2012 was 876 and 1148 respectively, and the average was 10 dissertations and theses eight/PPG. The relation of masters and doctors trained by DP was 3.3 postgraduate students/DP (1.8 teachers and 1.5 doctors). Compared to the three-year 20072009, an increase of titling masters and doctors (2.9 titled: 1.6 teachers and 1.3 doctors) $3,4,5$.

The trend of the relationship PhD/MD has been demonstrated by the evolution of reason of defended Theses/Dissertations since 1998 noting an increase of $72 \%$ in this relationship. Compared to all 48 areas, it is observed that the reason $\mathrm{PhD} /$ MD has been stable around 0.3 while in Medicine III is 0.8 . This data shows that there is increase of this ratio, yet undeveloped.

A benchmarking of the number of doctoral courses/total CPG and the number of post-graduate doctors/total titrated between the areas of Health Sciences, shows that Medicine III is the one with the highest percentage of PhD courses/total CPG and more doctors trained/total post-graduate students (Table 2).

TABLE 2 - " $n$ " doctorate courses/total CPG and " $n$ " titrated doctors/ total titrated in Health Science Area

\begin{tabular}{l|l|l} 
& "n" COURSES DOC- & "n" DOCTORATE \\
TORATE/TOTAL CPG & $\begin{array}{l}\text { TITRATEDTOTAL } \\
\text { TITRATED }\end{array}$ \\
\hline PHYSICAL EDUCATION & $25 / 77(32 \%)$ & $115 / 804(14 \%)$ \\
\hline NURSING & $27 / 85(31 \%)$ & $168 / 883(19 \%)$ \\
\hline PHARMACY & $29 / 82(35 \%)$ & $147 / 667(22 \%)$ \\
\hline MEDICINE I & $66 / 149(44 \%)$ & $500 / 1577(32 \%)$ \\
\hline MEDICINE II & $66 / 147(45 \%)$ & $459 / 1445(32 \%)$ \\
\hline MEDICINE III & $36 / 70(51,5 \%)$ & $308 / 669(46 \%)$ \\
\hline NUTRITION & $8 / 30(26 \%)$ & $35 / 276(12 \%)$ \\
\hline DENTISTRY & $52 / 148(35 \%)$ & $404 / 1599(25 \%)$ \\
\hline COLLECTIVE HEALTH & $25 / 97(25 \%)$ & $248 / 1082(23 \%)$ \\
\hline PHYSICAL EDUCATION & $25 / 77(32 \%)$ & $168 / 883(19 \%)$ \\
\hline TOTAL & $359 / 962$ & $2552 / 9885$
\end{tabular}

The scientific production (PC) is certainly the area highest point, that proud it very much, by its exponential progress of quality and by joining students production. The number of articles in the three-year periods 2007-2009 and 2010-2013 was very close, 5230 articles and 5338, respectively. However, there is a decrease in the strata articles $\angle B 3$ articles and an increase in $A 2, B 1$ and $B 2$ (Figure 2) ${ }^{4,5}$. Figure 2 shows an increase in publications Qualis A2 (424 to 934), B1 (706 to 1348) and B2 (835 to 1035). In the last three years, the proportion of articles published in high impact journals (A1 / A2 / B1 / B2) jumped from $30 \%$ to $50 \%$ of total PC in Medicine III. Almost PC A2 and B1 doubled showing that the scientific community has responded to the area policy. 


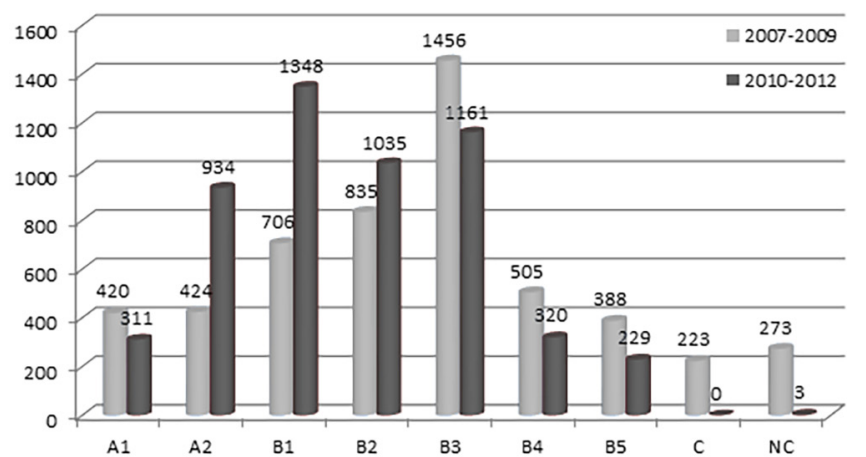

FIGURE 2 - Evolution of scientific production in Medicine III - threeyear periods 2007-2009 and 2010-2012

The development of high impact PC is important since the PC A1, A2 and B1 by the total of all articles of area PPG was 0.16 and 0.23 in periods 2007-2009 and 2010-2012. The same was observed analyzing high-impact PC in each PPG. The $P C A 1, A 2$ and $B 1$ of the total items in each DSP was 0.3 and 0.5 , respectively.

These data become more relevant when analyzing the evolution of the A1 journal of the FI area. In 2004-2006 the FI A1 was 2.3 in the period 2007-2009 was 3.2 and for the last evaluation of the 2010-2012 period was to 4. This FI to A1 was the biggest $\mathrm{Fl}$ in all areas of Health Sciences ${ }^{4,5}$.

For the first time the Medicine III reached the similar level of cut in the evaluation of scientific production (classification of journals in WebQualis) as Medicines I and II. Previously, the Medicine III FI was much lower than that of the Medicines I and II and the FI difference in the classification of journals was $>50 \%$. These data confirm the time to scientific consolidation achieved by Medicine III.

By analyzing worldwide data on the impact of the area and the scientific production (PC) observed that the medicine (including clinical and surgical specialties) remains as an area of greater impact and continues to qualitative and quantitative growth of constant and regular basis. Despite the peculiarities of each area, interdisciplinarity converged themes among the 47 areas facilitating the understanding and the deepening of knowledge, collaborating with the internationalization and strengthening the impact of its results.

Since 2007, Capes has a board, the International Relations, responsible for overseas exchanges and international cooperation. Even before the creation of this board Capes accounted for 2,977 scholarships in 2004 with a gradual increase in about 15\% per year until 2010 (4,346 scholarships). In 2011 the increasing grants was about 45\% from the 6,361 scholarships in 2012 and 2013 there were about 100\% increase, 12072 and 26433 respectively, with individual grants and international cooperation ${ }^{6}$.

The objectives of international cooperation is to promote new international research networks, development cooperation and the insertion of Brazilian science in the international arena and to promote research in areas of unconsolidated knowledge. In order to develop these activities of the Brazilian post-graduatioon in the global context, Capes maintains cooperation with over 40 countries, bilateral and bi-national university partnerships between Brazilian groups and abroad 6 .

The mechanisms by which these activities are developed include the financing of research projects, scholarship grant to our country and abroad, support for high level of mobility (abroad/ Brazil and Brazil/abroad), support for scientific events at home and abroad and funding for participation in international events. Since July 2011, were granted 86,100 scholarships in various supported modalities and the goal is to reach 101,000 (Table 3).
TABLE 3 - Number of scholarships in accordance with the modalities

\begin{tabular}{|l|l|l|}
\hline$\#$ & Modality & Total \\
\hline 1 & Sandwich graduation & 67.096 \\
\hline 2 & Sandwich doctorate & 8.135 \\
\hline 3 & Post-doctorate & 5.329 \\
\hline 4 & Full doctorate & 2.935 \\
\hline 5 & Scholarship for young talents Nisiting researcher & 2.009 \\
\hline 6 & Professional Master's abroad & 596 \\
\hline & Total & 86.100 \\
\hline
\end{tabular}

Source: Capes/CNPq - August 2014

The global implementation of such cooperation has shown that the most sought country destination was the United States $(27,100$ scholarships) followed by the United Kingdom $(9,735$ scholarships) and Canada (7,140 scholarships) ${ }^{6}$.

The greatest demand for international cooperation was in Engineering and other technological areas (37,179 scholarships) followed by Biology, Biomedical and Health Sciences $(15,087$ scholarships) ${ }^{6}$

The challenges identified from the area data document for FA of PPG were:

Challenge I - Decrease regional asymmetry ${ }^{4,5}$

In 2010-2012 triennial evaluation there was still no CPG in the North (N) or in the Midwest (CO) and there was important effort of the area in 2011 and 2012 in order to stimulate and advance programs in these regions. In 2011, with the support of Capes and FOPROP (Post-Graduation and Research Pro-Rectors Forum), the Medicine III Coordinator and two others consultants of the area together with Capes Evaluation Directory and Ceará Federal University (approved by a consultant in the area) went to the Advancement Meeting of Post-Graduation System in N, Northeast (NE) and CO regions of Brazil. This event mobilized all the Pro-Rectors of PG and research of private and public institutions in these regions. In response to this event, there were four CPG in N and NE. Unfortunately still failed to sensitize states on CO region and the importance of PPG to the scientific, social and economic development of region ${ }^{4,5}$.

Capes, with its three pillars - flexibility, speed and quality has worked in the inducible form, with specific notices, to meet strategic areas for the development of the country and regional asymmetry is an issue that continues to be relevant to all areas. Proposal would be an Induction Policy Innovation and Technology (Biomes and North and Midwest Flora) in clinical-surgical applicability.

Challenge II-Excellency titration on master and doctor degrees $3,4,5$ The vast majority of PPG Medicine III has titled masters and doctors in adequate numbers and in comparison with other areas of Health Sciences is the area that most doctors form in proportion to the total number of post-graduates. The reason $\mathrm{PhD} / \mathrm{MD}$ has increased in greater proportion compared to all 48 areas; however, the data demonstrate that there is an increase of this ratio, yet not sufficient.

The data has shown that the growth of PC monitors in parallel to the growing number of doctors since 1998 and that Brazil has about 1.4 doctors/1000 inhabitants between 25 and 64 years, while developed countries such as Switzerland and Germany, 23 and 15 doctors/1000 inhabitants. Given these facts, the challenge will be to continue increasing the ratio doctorate/ master and to correlate the master's and doctoral theses with the quality of the final product and find ways of attracting surgeons for $\mathrm{PG}^{3,4,5}$.

Challenge III - Scientific production ${ }^{4,5}$

In fact, Medicine III has shown great progress in scientific 
production and scientific maturity of its researchers. And the evaluation thermometer is the Impact Factor (IF) of the journals. However, Medicine III aims benchmarking with other areas of Health Sciences to analyze citations of articles, other evaluation factors and the impact on science and society.

Some questions should be answered by the researchers: What was the main finding of his research group? What other relevant contributions came from his research group? What scientific or technological relevance and impact to society? Changed paradigms?

Challenge IV - Reflection on national area journals $s^{4,5}$

Medicine III has stimulated the PC in national specialty journals in addition to the increased focus on impact of PC, and the impact of this was the passage of some national journals for upper strata. However, it has been stimulated the association of national and international journals of the various surgical specialties to raise the impact and increase the visibility.

In December 2011 Capes proposed to choose two areas journals to upgrade the Qualis and to have financial aid. Therefore, after discussion and voting at the meeting area and electronically, the indicated journals were Journal of the Brazilian College of Surgeons and the Brazilian Surgical Acta. To continue the upgrade, since the financial assistance was impossible, the area determined some goals to be achieved, for which evaluation is being elaborated by a sub-committee. Moreover, in the 2010-2012 period of evaluation was determined to account three articles in these journals per DP.

Challenge V - Internationalization ${ }^{6}$

Medicine III belongs to Biology, Biomedical and Health Sciences, the second area with more international exchanges; however, researchers in the area have requested and/or received too little. What has been observed over the last three study periods are requests for professional exchanges not linked with educational institutions.

Despite the efforts of Capes, it is observed that most of Medicine III programs display shy movement in this direction. Some aspects are relevant and deserve some considerations: the graduation training and internship include surgical practices unlike the Anglo-Saxon countries and the European community, vocational training is long (average age: 30 years), the need for postgraduate medical residency surgical practice, the scholarship for family income is insufficient, the re-employment period should be considered, among others.

Regardless of these factors, the area aims to optimize the internationalization, because the process of internationalization is essential for sustained growth strategy of the area production and the development of the country. The program experienced advances in this issue, unequivocally; the process generated a virtuous cycle which resulted in the establishment of research centers in a short time to reverse the flow, or composing centers of excellence attracting foreign researchers and students.

Thus, Medicine III will aim to continue stimulating and evaluating the six dimensions of Internationalization Index: articulated commitment, academic offerings, organizational infrastructure, attracting external resources, institutional investment and international student programs. The challenge is due to the metric indicator for evaluating the programs internationalization.

VI Challenge - Increase the CNPq Researcher " $n$ " 4,5

Increasing the number of CNPq researchers has been a reality, and the goal is to continue, as there is surgeons and researchers capacity, also demanding for technological improvement.

Medicine III has scheduled an event for the Area Discussion, with many of its stakeholders (state and federal development agencies, academies, universities and companies) to be held May 21, 2015.

Challenge VII - Inclusion of more post-docs

At the moment the formation of post-docs is essential to the advancement of the area, strengthens lines and research group, and has equivalence to co-supervisor teacher. The advantage is the academic practice, understanding the university administration and the scholarship is interesting (FAPESP value is greater than the assistant professor at a federal institution). The area challenge includes the creation of the post-docs evaluation indicators.

\section{Challenge VIII - Nucleation analysis of PPG 4,5}

In addition to the PC of DP analysis, compliance with the researcher nucleation is important for the continuity of the line and the research group and of the PPG; facilitates and coordinates with the analysis of the egressed students, allows strength and weakness analysis of each research group and where can act, and verifies if each teacher performs the primary function which is the training of human resources with quality (Figures 3 and 4).

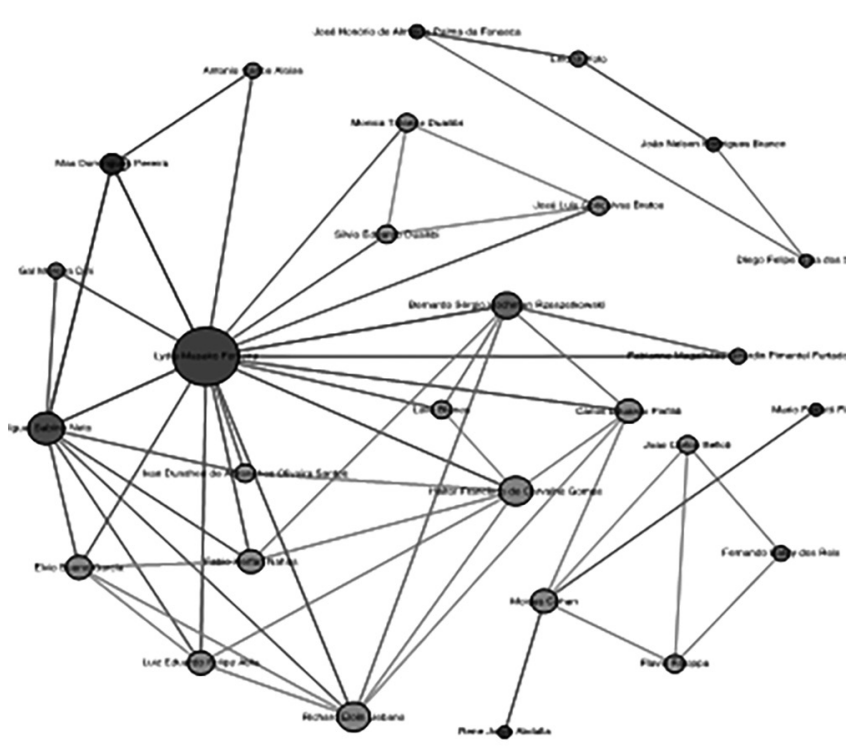

FIGURE 3 - Centralization Graph of researchers from Translational Surgery PPG of Federal University of São Paulo - UNIFESP $-2012$

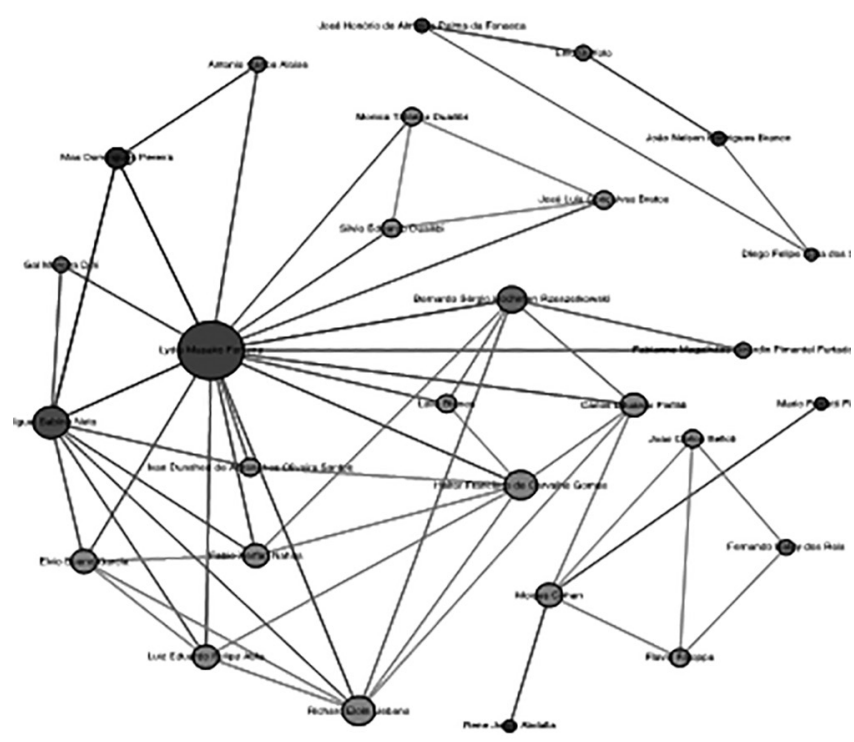

FIGURE 4 - Researchers Graph at the Translational Surgery PPG of Federal University of São Paulo - UNIFESP - ScripLattes 2013 with standard weight

Challenge IX - PPG $3 \times 3^{5}$

Note 3 for a PPG means that the program is regular and in general the new master programs start at this level to later reach higher ones. There are exceptions, like master starting with 
note 4 and doctorate with note 5 , but is not the rule in the area. Maintaining note 3 for nine years in a row concerns the viability of the course and therefore Capes determined collaborative actions to them. Thus, PPG scored a 3 for 3 consecutive three-year periods were analyzed and assembled to detect the strengths and weaknesses of the program in order to improve them, on-site visits with management, pro-rectors of postgraduation and research, DP, students in an attempt to solve the identified problems. Despite their efforts, the three PPG area maintained their note 3 , which can be explained by the insufficient time to substantially change the program.

Challenge $X$ - Inclusion high and fundamental school ${ }^{4,5}$

Since 2007 the mission of the Capes included promoting the training of qualified personnel for the improvement of basic education and the strengthening and growth of science, technology and innovation, aiming to sustainable and inclusive development in Brazil. The importance of including the primary and secondary education has been such that it currently the number of scholarships for this modality is equal to the number of scholarships for the PG.

Still incipient, but begin to emerge joint projects of researchers from several institutions like UNIFESP and UERJ along with postdoctoral students include high school students from public schools to work with.

Other suggestions have been given for this challenge: projects that students can meet the research lab, participate in studies, interact with undergraduates, PG, researchers, DP, DC and visitors, stimulus to reasoning projects, study, creation among others. Such action might in the long run attract these students to our activities.

\section{Challenge XI - Profissional master ${ }^{7}$}

It is essential to create alternative scientific technologies and technological research infrastructure, involved with the business sector. Over the past 15 years, the world has invested heavily in research, development and innovation by raising the value of US $\$ 600$ billion to US\$ 1.200 billion.

The need for training of postgraduate professionals able to develop new techniques and processes, able to reflect and act critically about their work process with applicability to society, raised the professional postgraduate modality.

For the area, this new strict sense modality associated with the need to analyze and evaluate other intellectual, scientific and technological production is a challenge. This subject will be addressed in another article in this supplement.

\section{Challenge XII - Solidarity 4,5}

It is one of the basic ethical principles of social organization, political and economic, and that has concern with the Common-Good without which the research, development and innovation has no value.

\section{RESUMO}

Objetivo: Descrever a situação atual da área Medicina III da Capes e detectar os desafios para o próximo quadriênio de avaliação. Métodos: Os documentos e relatórios de reuniões de área a partir de 2004 até 2013 da Medicina III da Capes foram lidos assim como os relatórios e as fichas de avaliação de cada Programa de Pós Graduação (PPG) da área e a subpágina da área no site da Capes. Os dados referentes ao Processo de Avaliação, à Ficha de Avaliação e aos dados do Corpo Docente, Discente e Produção científica de todos os PPG da Medicina III foram computados e analisados. A partir desses dados foram detectados os desafios da área para o próximo quadriênio (2013-2016). Resultados: Dentre os 3.806 PPG, a Medicina III apresentava 41 PPG durante última avaliação trienal e evoluiu de $18 \%$ para 43\% de PPG > conceito muito bom (Triênios 2001-2003 e 2010-2012). A maioria dos PPG se localizavam na Região Sudeste (32), três no Sul e dois no Nordeste. Não havia nenhum PPG no Norte ou Centro-Oeste. Em 2013 e 2014 foram aprovadas quatro mestrados profissionais e um mestrado e doutorado acadêmico. A média de docente permanente no triênio foi de 558 docentes com cerca de três alunos titulados/docente. O número de doutores titulados tem aumentado assim como a razão Doutorado/Mestrado. A proporção de publicações em periódicos de maior impacto (A1, A2, B1 e B2) saltou de 30\% para 50\% demonstrando resposta positiva da comunidade à política da área. Os desafios detectados foram: diminuir assimetria regional, elevar o número de mestres e doutores de excelência, reavaliação das revistas nacionais, estimular e definir indicadores de internacionalização, inclusão de pós-doutores e definição de seus indicadores, análise da nucleação do PPG, PPG 3×3, inclusão ensino médio e fundamental, mestrado profissional e indicadores da produção científico-tecnológica e solidariedade. Conclusão: A Medicina III tem se consolidado cientificamente e seus pesquisadores demonstraram maturidade científica chegando a um patamar elevado e igualado às áreas de maior tradição e história. Para a manutenção e avanço da área alguns desafios e metas foram traçadas para serem desenvolvidas no quadriênio $2013-2016$.

Descritores: Educação a pós-graduação em Medicina. Avaliação educacional. Educação superior. Avaliação da pesquisa em saúde. Avaliação de programas e instrumentos de pesquisa.

\section{REFERENCE}

1. Fundação CAPES - Ministério da Educação. Disponível em: http:// www.capes.gov.br/avaliacao. Acesso em 13/02/2015.

2. Fundação CAPES - Ministério da Educação. Mestrado e Doutorado Reconhecidos. Disponível em: http://conteudoweb.capes.gov.br/ conteudoweb/ProjetoRelacaoCursosServlet?acao=pesquisarRegiao. Acesso 17/02/2015

3. Fundação CAPES - Ministério da Educação. Mestrado e Doutorado Reconhecidos. Disponível em: http://conteudoweb.capes.gov.br/conteudoweb/ProjetoRelacaoCursosServlet?acao=pesquisarAreaAvaliacao. Acesso 17/02/2015

4. Documento de área e Comissão da Trienal 2013. Área Medicina III. Disponível em: http://capes.gov.br/images/stories/download/avaliacaotrienal/Docs_de_area/Medicina_III_doc_area_e_ comiss\%C3\%A3o_att08deoutubro.pdf. Acesso em 15/11/2014.
5. Fundação CAPES - Ministério da Educação. Medicina III. Disponível em:http://www.capes.gov.br/component/content/article/44-avaliacao/4633-medicina-iii. Acesso em 15/11/2014.

6. Fundação CAPES - Ministério da Educação. Disponível em:

7. http://capes.gov.br/cooperacao-internacional. Acesso em 15/11/2014.

8. Fundação CAPES - Ministério da Educação. Mestrado Profissional: o que é? Disponível em: http://www.capes.gov.br/avaliacao/ sobre-a-avaliacao/mestrado-profissional-o-que-e. Acesso em $13 / 02 / 2015$.

Received on: 19/02/2015

Accepted for publication: 12/09/2015:

Conflict of interest: none

Source of funding: none

Address for correspondence:

Lydia Masako Ferreira

lydiamferreira@gmail.com 